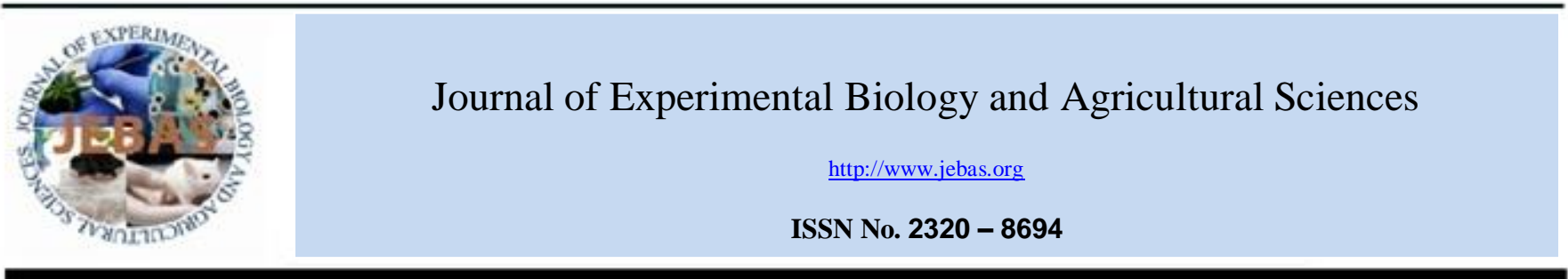

\title{
PERFORMANCE OF WHEAT CULTIVARS UNDER IRRIGATED LATE SOWN CONDITION
}

\author{
K.M. Singh ${ }^{1}$, H. K. Singh ${ }^{1} *$ R. K. Sohane ${ }^{2}$, Ashutosh $\operatorname{Singh}^{3}$ \\ ${ }^{1}$ Krishi Vigyan Kendra, Kishanganj, Bihar 855107 \\ ${ }^{2}$ Directorate of Extension Education, Bihar Agricultural University, Sabour, Bihar-813210 \\ ${ }^{3}$ Department of Soil Science, Bihar Agricultural University, Sabour, Bihar-813210
}

Received - July 31, 2017; Revision - August 28, 2017; Accepted - September 03, 2017

Available Online - September 10, 2017

DOI: http://dx.doi.org/10.18006/2017.5(4).472.475

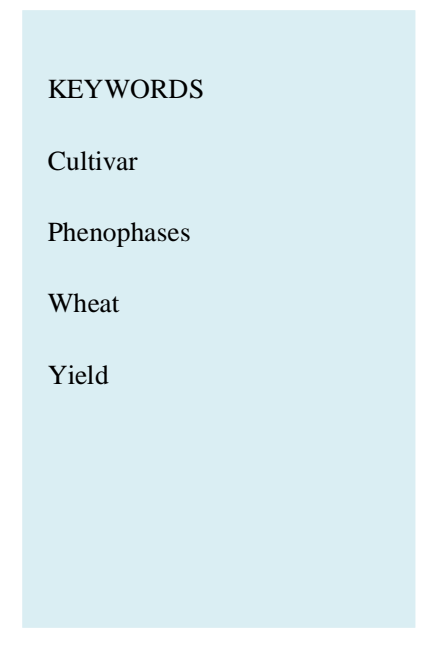

\begin{abstract}
Delay in time of sowing in rice-wheat cropping system is perhaps the one of the major factors responsible for low crop yield. An experimenton the wheat cultivars viz.DBW 14, BR 934, HI 1563, HD 2985 and NL was conducted on farmers field under irrigated late sown condition in Kishanganj district of Bihar, India during the Rabi season of 2014-15 \& 2015-16. Results of study revealed that cultivar HD 2985 had highest grain yield ( $31.0 \mathrm{q} / \mathrm{ha}$ ) as compared to the farmers local variety $\mathrm{NL}(23.20 \mathrm{q} / \mathrm{ha})$. The improvement in yield of wheat under said treatment might be due to favorable growth and yield contributing characters (plant height, effective tillers $/ \mathrm{m}^{2}$, spike length, number of grains/spike and test weight). This treatment also recorded higher in net return (Rs. 25,500/ha) and B:C ratio (2.32). The cultivar HD 2985 required more number of days to attain development and accumulated maximum degree day at phenophases in wheat. The farmers under test were satisfied with the technology of improved seed of wheat HD 2985 for its cultivation in irrigated late sown condition (10-25 December) for obtaining higher yield and profit.
\end{abstract}

* Corresponding author

E-mail: horthemant16@gmail.com (H. K. Singh)

Peer review under responsibility of Journal of Experimental Biology and Agricultural Sciences.

Production and Hosting by Horizon Publisher India [HPI] (http://www.horizonpublisherindia.in/).

All rights reserved.
All the article published by Journal of Experimental Biology and Agricultural Sciences is licensed under a Creative Commons Attribution-NonCommercial 4.0 International License Based on a work at www.jebas.org.

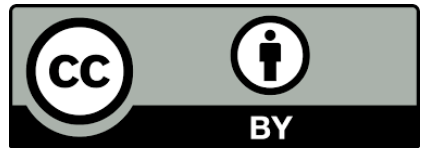




\section{Introduction}

Wheat (Triticum aestivum L.) has a prominent position among the cereals that supplement nearly one third of the total world population's diet. It occupies an area of 31.19 million hectares with production of 95.91 million tones and productivity of 3075 $\mathrm{kg} / \mathrm{ha}$ in India (Anonymous, 2014). It is an important crop of Rabi season in Bihar covering an area of 2.26 million hectares with production and productivity of 5.08 million tones and 2251 $\mathrm{kg} / \mathrm{ha}$, respectively during 2013-14 (Anonymous,2014). Wheat has significant area of about 16670 ha in Kishanganj district of Bihar with an average productivity of $1693 \mathrm{~kg} / \mathrm{ha}$ (Anonymous, 2016). The region specific significant efforts were carried out to reduce the enormous gap between actual production and production potential of wheat cultivars through available technological interventions in different agro-ecological environments. The level of self-sufficiency will not be achieved unless researchers and extension personals manage to make better use of resources in new arena of climate change and appropriate location specific transfer of agricultural technology.

Seasonal fluctuations in temperature have potential impact on the growth stages development and grain yield of crops. Wheat, being a winter cereal requires particular environmental condition for better emergence, growth and flowering and is more vulnerable if exposed to high temperatures during reproductive stages (Kalra et al., 2008). In India, terminal heat stress is a major reason of yield decline in wheat due to delay in planting (Joshi et al., 2007). Late planted wheat suffers drastic yield losses which may exceed to 40$50 \%$. Global climate models predict an increase in mean ambient temperature between 1.8 and $5.8^{\circ} \mathrm{C}$ by end of this century (Anonymous, 2007). Hobbs \& Morris (1996) observed 1\% decrease for each day that wheat sowing was postponed after the optimum sowing date (15-20 November). Grain yield was negatively related to the thermal time accumulated above the base temperature of $31^{\circ} \mathrm{C}$ (Mian et al., 2007). High temperature above $32^{\circ} \mathrm{C}$ has been reported to reduce grain yield and grain weight (Wardlaw et al., 2002). Shrivelled small grains are produced and different yield associated traits such as tillering, grain weight and grains numbers/spike are reduced. Using this factor 3-4 \% loss in yield was reported per $10^{\circ} \mathrm{C}$ temperature rises above from 15 $20^{\circ} \mathrm{C}$, it can be calculated that most commercially sown wheat cultivars in India would lose approximately $50 \%$ of their yield potential when exposed to $32-38^{0} \mathrm{C}$ temperature at the crucial grain formation stage (Dwivedi et al., 2015)

The farmers of Kishanganj district generally make delayed in sowing of wheat (10Dec-10 Jan) mainly due to practice of growing long duration paddy varieties, late release of accumulated water and more time consumed for land preparation resulting into poor yield of the crop.In India terminal heat stress is a major reason of yield decline in wheat due to delayed planting (Joshi et al., 2007). Selection of suitable crop varieties according to the agro-climatic conditions may play crucial role in realizing the optimum production of any crop commodity (Singh et al., 2008). Keeping in the view to improve the productivity of wheat in late showing condition, this study was arranged to evaluate the new varieties of wheat on farmer's field under irrigated late sown condition in Kishanganj district of Bihar.

\section{Materials and Methods}

The present investigation was conducted on farmer's field during 2014-15 \& 2015-16 for performance of wheat cultivars under irrigated late sown condition in Kishanganj district of Bihar. The experiment was laid out on farmer's field in randomized block design with 10 replications and plot size of 0.1 ha. The four (4) high yielding varieties of wheat namely DBW 14, BR 934, HI 1563 and HD 2985 were tested with farmer' s local variety NL. The study area is situated under subtropical climate with extremes of temperature in summer $46^{\circ} \mathrm{C}$ and in winter $4^{\circ} \mathrm{C}$ and the area receives the annual precipitation of $1200-1400 \mathrm{~mm}$. The crop was grown with recommended seed rate of $125 \mathrm{~kg} / \mathrm{ha}$ and fertilizer dose of 120:60:40 kg N: $\mathrm{P}_{2} \mathrm{O}_{5}: \mathrm{K}_{2} \mathrm{O} / \mathrm{ha}$ under irrigated condition. The soil was sandy loam in texture having initial soil fertility status like, $\mathrm{pH} 6.8$, organic carbon 0.48 per cent, available $\mathrm{N}, \mathrm{P}_{2} \mathrm{O}_{5}$ and $\mathrm{K}_{2} \mathrm{O} 224,18$ and $116 \mathrm{~kg} / \mathrm{ha}$, respectively. Need based all the agronomic management practices were followed and kept uniform. Meteorological data in cropping period at the experimental site revealed the highest temperature $\left(31.61^{\circ} \mathrm{C}\right)$ in March and the lowest $\left(10.47^{\circ} \mathrm{C}\right)$ in January and maximum in April $\left(34.70^{\circ} \mathrm{C}\right)$ and minimum in January $\left(9.5^{\circ} \mathrm{C}\right)$ of $2014-15$ and $2015-$ 16 , respectively. The crop received rain showers from October to September. Figure 1 and Figure 2 shows the climatic situation

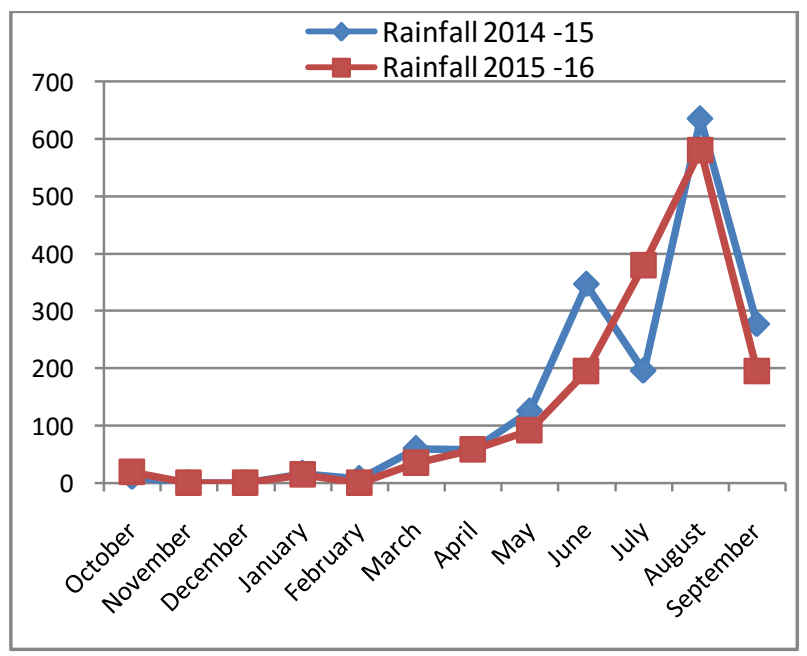

Figure 1 Meteorological observations of rainfall during 2014-15 \& 2015-16. 


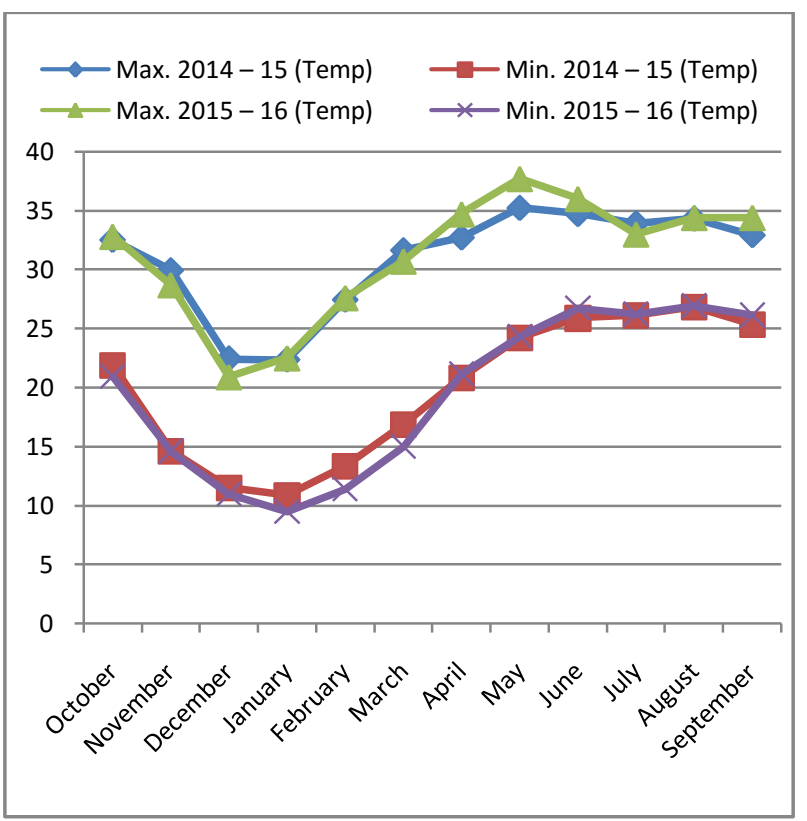

Figure 2 Meteorological observations of temperature during 2014-15 \& 2015-16.

during the crop growth period. Plant samples were collected randomly to number of effective tillers $/ \mathrm{m}^{2}$, length of spike $(\mathrm{cm})$, number of grain/spike, 1000-grain weight. (g), grain yield $\left(\mathrm{kg} \mathrm{ha}^{-1}\right)$. The data were analyzed statistically using analysis of variance (ANOVA) and significant means were separated using least significance difference (LSD) test. The heat unit requirement or growing degree day at phenophases of wheat was calculated considering mean maximum and minimum temperature during that day and base temperature $\left(5^{\circ} \mathrm{C}\right)$ below which growth does not occur (Pal et al., 1996).

\section{Results and Discussion}

The cultivar HD 2985 recorded higher grain yield $(31.0 \mathrm{q} / \mathrm{ha})$ which was at par with the cultivar HI 1563(30.20 q/ha) followed by DBW $14(23.2 \mathrm{q} / \mathrm{ha})$ in comparison to farmers local variety NL ( $23.20 \mathrm{q} / \mathrm{ha})$. There was $7.2 \mathrm{q} / \mathrm{ha}(33 \%)$ more grain yield produced by cultivar HD 2985 in comparison to farmer'slocal variety NL.The cultivars showed their significant difference on all yield contributing parameters. The yield attributing characters were also significantly higher in cultivar of HD 2985 with respect to others and poor expression by farmers local variety. The cultivar HD2985 produced the maximum number of effective tillers $/ \mathrm{m}^{2}$ (329), number of grain per spike (52), spike length $(30 \mathrm{~cm})$ and 1000 grain weight $(42.6 \mathrm{~g})$ are reported minimum in farmer's local variety NL (Table1).

The different wheat cultivars influenced the days taken to phenophases, $50 \%$ flowering and maturity in wheat as a result the
Table 1 Performance of five wheat cultivars on yield and yield attributing characters

\begin{tabular}{|lllll|ll|}
\hline $\begin{array}{l}\text { Sl. } \\
\text { No. }\end{array}$ & Varieties & $\begin{array}{c}\text { No. of } \\
\text { effective } \\
\text { tillers/ } \\
\mathrm{m}^{2}\end{array}$ & $\begin{array}{c}\text { Length } \\
\text { of } \\
\text { spike } \\
\text { (cm) }\end{array}$ & $\begin{array}{c}\text { No. } \\
\text { of } \\
\text { grain/ } \\
\text { spike }\end{array}$ & $\begin{array}{c}1000- \\
\text { grain } \\
\text { wt. } \\
\text { (gm) }\end{array}$ & $\begin{array}{c}\text { Grain } \\
\text { Yield } \\
(\mathrm{q} / \mathrm{h})\end{array}$ \\
\hline 1. & $\begin{array}{l}\text { Farmers } \\
\text { local(NL) }\end{array}$ & 302 & 17 & 30 & 36.6 & 23.2 \\
\hline 2. & DBW 14 & 305 & 16.5 & 34 & 37.2 & 25.2 \\
\hline 3. & BR-934 & 314 & 20.0 & 39 & 41.0 & 26.8 \\
\hline 4. & HI 1563 & 318 & 25.4 & 46 & 41.8 & 30.2 \\
\hline 5. & HD-2985 & 329 & 30.0 & 52 & 42.6 & 31.0 \\
\hline & $\begin{array}{l}\text { CD at } \\
5 \%\end{array}$ & 3.5 & 2.7 & 1.7 & 0.8 & 6.3 \\
\hline
\end{tabular}

Data given in table are mean of two years

heat unit requirement at respective phenophases. The cultivar HD 2985 and NL take 72 and 115 days for $50 \%$ flowering and maturity stage, respectively. HD 2985 required more degree days (897.7 degree day) for 50\% flowering and 1741.9 degree day at maturity in comparison to that of other cultivars (Table 2).Results of present study are in agreement with the findings of Sattar et al. (2010). High temperature induces modifications in plants may be direct as on existing physiological process or indirect in changing the pattern of development (Downton \& Slatyer, 1972). High temperature affects the period of grain fillingand fertilization process resulting in reduced development of grain ultimately decreasing the crop yield.

Table 2 Days taken to phenophases and heat unit requirement of wheat cultivars

\begin{tabular}{|c|c|c|c|c|}
\hline \multirow[t]{3}{*}{ Varieties } & \multicolumn{2}{|c|}{ Days to Phenophase } & \multicolumn{2}{|c|}{$\begin{array}{l}\text { Heat unit requirement } \\
\text { (degree day) }\end{array}$} \\
\hline & $50 \%$ & Maturity & $50 \%$ & Maturity \\
\hline & Flowering & & Floweri & \\
\hline $\begin{array}{l}\text { Farmers } \\
\text { Local(NL) }\end{array}$ & 72 & 110 & 897.7 & 1634.9 \\
\hline DBW 14 & 71 & 108 & 878.0 & 1590.6 \\
\hline BR 934 & 70 & 106 & 860.4 & 1549.1 \\
\hline HI 1563 & 71 & 112 & 878.0 & 1677.0 \\
\hline HD 2985 & 72 & 115 & 897.7 & 1741.9 \\
\hline
\end{tabular}

Maximum net return with B:C ratio was obtained under HD-2985 (Rs.25500/ha with 2.32) followed by HI 1563 (Rs.24390/ha with 2.25), BR934 (Rs.19490/ha with 2.01), DBW 14 (Rs.17140/ha with 1.88) and minimum by farmers variety NL (Rs. 15340/ha with 1.84)(Table 3).

The early sowing resulted in better development of the grain due to longer growing period. This is because of the fact that timely sown wheat had more time for dry matter accumulation to produce higher grain yield (Spink et al., 2000; Shahzad et al., 
2002). The differential behavior of wheat genotypes with heat stress environment in eastern indo-gangetic plains of Bihar have been reported by Dwivedi et al. (2015). It is believed to have a protected role under environmental stress in late planting wheat (Reynolod et al., 2001). There is direct linear relationship of growth and rate of development of crop with temperature (Castillo \& Santibanez, 1987).The concept of heat unit requirement is based on idea that plants have definite temperature regime for growth and development. Heat unit requirement is used to predict the onset of different phenophases of crop as a guide in planning strategies for realizing higher yield of the crops. Ghadekar et al. (1992) reported that wheat crop accumulated mean degree day of 1689.80 from sowing to maturity.

In summarizing the above result, it could be stated that cultivar HD-2985 out yielded others cultivar and performed well under late sown condition inrice-wheat cropping system. The farmers under test were satisfied with the technology of improved wheat cultivar HD 2985 for its cultivation in irrigated late sown condition (10-25 December) for obtaining higher yield and profit.

\section{Conclusion}

It is concluded from this study that wheat variety HD-2985 performed well under irrigated late sown condition under ricewheat cropping system in Kishanganj district of Bihar.

\section{References}

Anonymous (2014) Agricultural Statistics At a glance -2014. Directorate of Economics and Statistics, Department of Agriculture and Cooperation. Ministry of Agriculture, Government of India Pp.75-77.

Anonymous (2016) Potential Linked Credit Plan 2016-17, NABARD, Kishanganj Pp.6-8.

Castillo GH, Santibanez QF (1987) Effect of temperature on phenology of wheat. Agricultura Tecnica 47:29-32.

Downton J, Slatyer RO (1972) Temperature dependence of photosynthesis in cotton. Plant Physiology 50: 518-522.

Dwivedi SK, Kumar S, Prakash V (2015) Effect of late sowing on yield and yield attributes of wheat genotypes in astern IndoGangetic Plains. Journal of Agricultural Search 2:304-306.

Ghadekar SR, Khattar KD, Chipale DL, Das SN (1992) Studies on growth, development, yield and photothermal unit requirement of wheat at Nagpur. Indian Journal of Agricultural Science 58:195-204.

Hobbs PR, Morris ML (1996) Meeting South Asia's Future Food Requirements from Rice-Wheat Cropping Systems: Priority Issues
Facing Researchers in the Post Green Revolution Era. Mexico, D.F.CIMMYT Natural Resources Group Pp. 96-01.

Anonymous (2007) Intergovernmental Panel on Climate Change fourth assessment report: Climate change 2007. Synthesis Report World Meteorological Organization, Geneva, Switzerland Pp. 104.

Joshi AK, Chand R, Arun B, Singh RP, Ortiz Ferrara G (2007) Breeding crops for reduced-tillage management in the intensive, rice-wheat systems of South Asia. Euphytica 153:135-151.

Kalra N, Chakraborty D, Sharma A, Rai HK, Jolly M, Chander S, Kumar PR, Bhadraray S, Barman B, Mittal RB, Lal M, Sehgal M (2008) Effect of increasing temperature on yield of some winter crops in northwest India. Current Science 94 : 82-88.

Mian MA, Mahmood A, Ihsan M, Cheema NM (2007) Response of different wheat genotypes to post anthesis temperature stress. Journal Agricultural Research 45: 269-276.

Pal SK, Verma UN, Singh MK, Thakur R (1996) Heat unit requirement of phonological development of wheat. Indian Journal of Agricultural Science 66:397-400.

Reynolds MP, Nagarajan S, Razzaue A, Agneeb OAA (2001) Heat tolerance In: Qrtiz -monasterio JI, Mc A (Eds.) Application of physiology in wheat breeding Nab .CIMMYT, Mexico Pp. 124-135.

Sattar A, Cheema MA, Farooq M, Wahid MA, Wahid A, Babar BH (2010) Evaluating the performance of wheat cultivars under late sown conditions. International Journal of Agriculture and Biology 12 : 561-565.

Shahzad K, Bakht J, Shah WA, Shafi M, Jabeen N (2002) Yield and yield components of various wheat cultivars as affected by different sowing dates. Asian Journal Plant Science 1:522-525.

Singh AK, Manibhushan CN, Bharati RC (2008) Suitable crop varieties for limited irrigated conditions in different agro climatic zones of India. International Journal Tropical Agricultural 26 : 491-496.

Spink JH, Kirby EJM, Forest DL, Sylvester-Bradley R, Scott RK, Fouke's MJ, Clare RW, Evans EJ (2000) Agronomic implications of variation in wheat development due to variety, sowing, site and season. Plant, Variety and Seed 13: 91-105.

Wardlaw IF, Blumenthal C, Larroque O, Wrigley CW (2002) Contrasting effects of chronic heat stress and heat shock on grain weight and flour quality in wheat. Functional Plant Biology 29: 25-34. 